\title{
Polycyclic aromatic hydrocarbons (PAHs), arsenic, chromium and lead in warty crab (Eriphia verrucosa): occurrence and risk assessment
}

\author{
Sara Lambiase ${ }^{1} \cdot$ Andrea Ariano $^{2} \cdot$ Francesco Paolo Serpe $^{1} \cdot$ Marcello Scivicco $^{2} \cdot$ Salvatore Velotto $^{2}$. \\ Mauro Esposito $^{1} \cdot$ Lorella Severino $^{2}$
}

Received: 4 January 2021 / Accepted: 7 June 2021 / Published online: 15 June 2021

(C) The Author(s) 2021

\begin{abstract}
This study assesses the PAH and heavy metal levels in muscle of warty crabs (Eriphia verrucosa), from the northern coast of the Campania region improving the data on toxic contaminants in this crustacean. The results showed a minimal PAH contamination; the mean concentrations were as follows: $0.2,1.6$ and $1.7 \mu \mathrm{g} \mathrm{kg}^{-1}$ wet weight (ww) for BaP, PAH4 and PAH6, respectively. Regarding the levels of the two PAHs not included in the European regulations, the BkF mean concentration was $0.1 \mu \mathrm{gg}^{-1} \mathrm{ww}$, while $\mathrm{DahA}$ was detected only in $10.7 \%$ of samples. $\mathrm{Pb}$ and $\mathrm{Cr}$ were also detected at low levels with mean values of 0.068 and $0.468 \mathrm{mg} \mathrm{kg}^{-1} \mathrm{ww}$, respectively; instead, high As levels, with a mean value of $5.021 \mathrm{mg} \mathrm{kg}^{-1} \mathrm{ww}$, were found. Considering the EWIs and the ILCRs calculated in this study, the $\mathrm{PAH}, \mathrm{Pb}$ and $\mathrm{Cr}$ contamination levels found in the edible part of the crabs resulted safe for human consumption. Contrariwise, the ILCR calculated for the As exceeded the acceptable level of cancer risk, although the calculation did not refer to the inorganic form which is the only one recognized as carcinogenic. Hence, this study shows that warty crabs can accumulate environmental contaminants in their muscle tissue representing an important route of exposure to these toxics for the local population that regularly consumes them. This finding highlights the importance of monitoring the presence of these pollutants in crabs and in general in all fish and seafood in order to ensure food safety for consumers.
\end{abstract}

Keywords Heavy metal $\cdot$ PAH $\cdot$ Eriphia verrucosa $\cdot$ Estimated weekly intake $\cdot$ Incremental lifetime cancer risk

\section{Introduction}

Over the last decades, interest and awareness of institutional bodies, researchers and consumers in seafood safety have increased significantly. Fishes, mussels and crustaceans are part of the culinary traditions of several countries worldwide and represent an essential source of nutrients being rich in proteins, fatty acids, essential amino acids and vitamins (Cederholm

Responsible Editor: V. V.S.S. Sarma

Andrea Ariano

andrea.ariano@unina.it

1 Istituto Zooprofilattico Sperimentale del Mezzogiorno, 80055 Portici, Italy

2 Department of Veterinary Medicine and Animal Production, Division of Toxicology, University of Naples Federico II, 80137 Naples, Italy
2017). Despite this, seafood can represent also a route of human exposure to dangerous chemical substances. Seafood safety is strictly linked to marine environment quality because many pollutants present in the aquatic environment can be bioaccumulated and biomagnified by marine organisms; therefore, concerns have been raised about the potential risks for human health derived by the consumption of contaminated fisheries products (Cappello et al. 2018). The Mediterranean Sea, as a semi-enclosed basin characterized by an intense naval traffic and industrial coastal activity, represents a geographic area highly sensitive to environmental pollution (Ferrante et al. 2018). Therefore, seafood from Mediterranean basin deserves to be carefully analysed to guarantee the safety of consumers and to provide reliable scientific data that can be exploited by the institutions to implement the panel of necessary analyses to maintain high standards of food safety and quality. Moreover, the monitoring of some aquatic species, because of their natural habitat, diet and position in the food chain, represents a useful bioindicator to collect data on the current health status of the 
marine ecosystem. Eriphia verrucosa is a benthonic species of crustacean, also called the warty crab, that lives in shallow waters up to the rocky coastlines. It is a common species in the Mediterranean Sea, regularly found along the Italian Tyrrhenian coasts, feeding primarily on bivalves, gastropods and polychaetes. Moreover, the warty crab is part of the traditional cuisine of southern Italy, especially of Campania region, and is widely consumed by the local population (Ariano et al. 2015). Eriphia verrucosa fishing takes place throughout the year and without limitations for both professional and not professional fishing. There are no minimum sizes to be respected for their fishing. The warty crab, because of its geographic distribution, position in the food web and consumption by humans, represents an optimal marine species for quali-quantitative toxicological investigations. Among numerous contaminants present in the marine environment, polycyclic aromatic hydrocarbons (PAHs) are persistent pollutants widely diffused, in particular in harbours, estuaries and coastal waters. They originate from incomplete combustion and pyrolysis of organic material, in processes as fossil fuel combustion, waste incineration and accidental oil spills (Tornero and Hanke 2016; Habibullah-AlMamun et al. 2019). PAHs are chemicals characterized by strong lipophilicity, solubility in organic solvents and high boiling and melting points. Living organisms can be exposed to PAHs through different routes, as inhalation or dermal contact, but primarily through ingestion that is considered the mainly way of exposure causing detrimental effects on animals and human health (Ferrante et al. 2018; Zaccaroni et al. 2018).

Based on the evidence of their toxic potential, European institutions have issued two regulations regarding presence of PAHs in food for human consumption: the Commission Regulation (EC) 1881/2006 2006and its amendment (Commission Regulation (EU) 835/2011 2011) that establishes the maximum levels (MLs) in molluscs and some smoked fish products of four PAH compounds (benzo[a]pyrene (BaP), benzo[a]anthracene (BaA), benzo[b]fluoranthene $(\mathrm{BbF})$ and chrysene (Cry)) and the Commission Regulation (EC) 333/2007 2007and its amendment (Commission Regulation (EU) 835/2011 2011) that defines the sampling and analytical methods approved for PAH detection in food products. The need to officially assess the presence of PAHs in food items and to set MLs that safeguard the public health is linked to the high toxicity of these chemicals. The International Agency for Research on Cancer (IARC) listed sixteen different PAHs as dangerous compounds for human health due to their ability to be potentially carcinogens and mutagens (IARC (International Agency for Research on Cancer) 2013). Despite this, the EC regulation considers just four PAH compounds for which research in products intended for human consumption is mandatory. Moreover, EC regulation limits the research of PAHs only to two categories of fishery products: bivalve molluscs and muscle meat of smoked fish and smoked fishery products.
Among dangerous pollutants which can induce detrimental effects on human health, interfering with immune and reproductive systems, also trace elements can represent a risk for usual consumer of warty crabs. Although data regarding trace elements concentrations in warty crab are poor (Durmus et al. 2018; Zotti et al. 2016), Ariano et al. (2015) reported high concentrations of cadmium $(\mathrm{Cd})$ in this crustacean (whole animal) that could lead to health risks for the population that usually consume this seafood. For this finding and considering that marine environment is affected by other toxic metals, this study also intends to assess the contamination levels of arsenic (As), chromium $(\mathrm{Cr})$ and lead $(\mathrm{Pb})$ which are elements very relevant for food safety. These metals are widespread and persistent pollutants which can be found at high concentrations in marine environment close to greatly urbanized and industrialized areas such as coastal areas, estuaries and river mouths (Maulvault et al. 2015). These elements are well known for their ability to induce harmful effects both in acute and chronic exposures; moreover, it has been reported that toxic metals as $\mathrm{Pb}$ can provoke severe health disease even at sub-lethal concentrations (Durmus et al. 2018). Human exposure occurs mainly through food consumption; in particular, fish and seafood are recognised as the mainly contributors to human As intake (Molin et al. 2015).

The aim of the present study is to evaluate PAHs, As, Cr and $\mathrm{Pb}$ concentrations in muscle of the warty crabs. In addition to the assessment of the four PAH compounds included in the European regulations for food safety and quality, we investigated also the presence of benzo[k]fluoranthene $(\mathrm{BkF})$ and dibenzo[a,h]anthracene (DahA) which show a similar toxicity (Lundstedt et al. 2007; Spink et al. 2008).

\section{Materials and methods}

\section{Biological material}

Twenty-eight samples of warty crab (Eriphia verrucosa) were caught from two different locations, Castelvolturno (site A) and Naples (site B), located along the northern coast of the Campania region (Italy) (Fig. 1). All samples were collected between May and July 2016.

Once captured, the crabs were euthanized at $-80{ }^{\circ} \mathrm{C}$ for 30 min. Then, the animals were weighed and measured using an Absolute Digimatic Caliper (Mitutoyo, Japan). The length (cl) and width (cw) of their carapace ranged between 3.8 and $6.0 \mathrm{~cm}$ (mean value: $4.9 \mathrm{~cm}$ ) and 5.0 and $8.0 \mathrm{~cm}$ (mean value: $6.2 \mathrm{~cm}$ ), respectively. Then the crabs were immediately sealed in decontaminated polyethylene bags, frozen at $-20{ }^{\circ} \mathrm{C}$ and kept at the same temperature until delivery to the laboratory where they were dissected using steel tools including forceps, scissors straight and scalpels and analysed. 


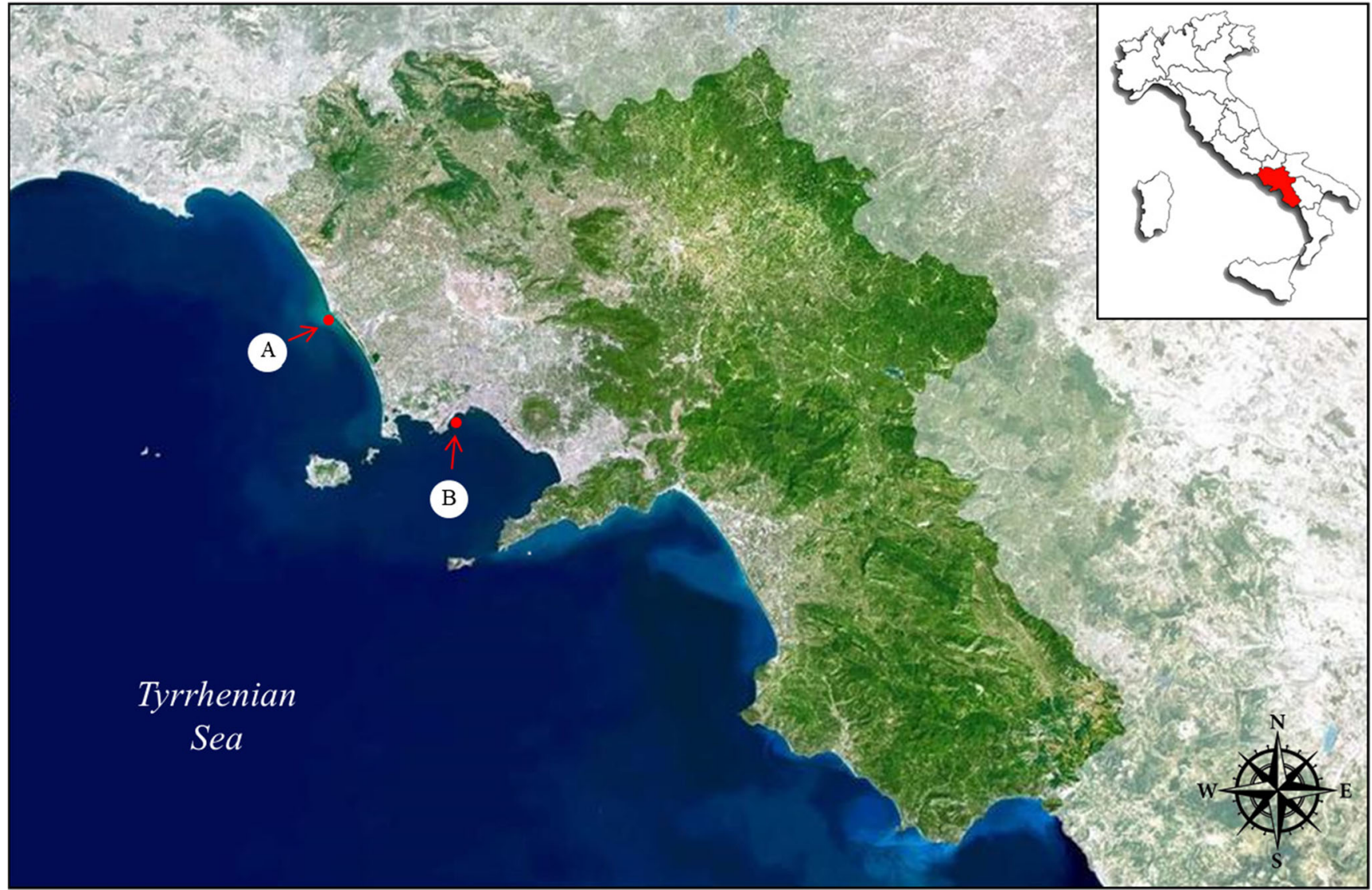

Fig. 1 Map showing locations of the sampling sites: Castelvolturno (site A) and Naples (site B) in Campania region, Italy

\section{Analysis of polycyclic aromatic hydrocarbons}

Analysis of polycyclic aromatic hydrocarbons was performed according to the procedure described by Serpe et al. (2010). In brief, the crab muscle from claws and appendages was individually separated, homogenized and weighed $(2.0 \pm 0.5 \mathrm{~g})$. Each sample was saponified with $10 \mathrm{~mL}$ of a solution of potassium hydroxide ( $2 \mathrm{~N}$ in ethanol) and liquid/liquid extracted for three times with $20 \mathrm{~mL}$ of cyclohexane. The extract was filtered, reduced to small volume and purified using a silica Sep-Pak cartridge and eluted with acetonitrile (ACN). The instrumental analysis were carried out by a high performance liquid chromatograph (HPLC) equipped with a fluorescence detector (Waters Alliance). Chromatographic separation was performed by an EnviroSep PP $(125 \times 3.2 \mathrm{~mm}$, particle size $5 \mathrm{um}$, Phenomenex) LC column using the gradient elution with acetonitrile and ultrapure water as solvents at $0.5 \mathrm{~mL} \mathrm{~min}^{-1}$. The fluorescence detection was performed at the excitation and emission wavelengths of 294 and $404 \mathrm{~nm}$, respectively. External standard method was used to determine PAH concentration in the samples. Linearity of method was checked by triple injection of standard solution at concentrations between 0.4 and $20.0 \mathrm{ng} \mathrm{mL} \mathrm{mL}^{-1}$ obtaining a correlation coefficient $\left(\mathrm{r}^{2}\right)$ at least 0.999 . The calibration curve was made for every sequence of analysis. The limit of quantification (LOQ) was $0.2 \mu \mathrm{g} \mathrm{kg}^{-1}$ for each PAH.

\section{Analysis of heavy metals}

Glassware and laboratory equipment were decontaminated before use with diluted ultrapure $65 \% \mathrm{HNO}_{3}$ (ROMIL-UpA, Cambridge, UK) and were rinsed with Milli-Q water (Millipore Corp., Bedford, MA).

For the analysis, the crab samples $(0.50 \pm 0.02 \mathrm{~g})$ were weighed in Teflon vessels with $5.0 \mathrm{~mL}$ of $69 \% \mathrm{HNO}_{3}$ and $2.0 \mathrm{~mL}$ of $30 \% \mathrm{H}_{2} \mathrm{O}_{2}$ (ROMIL-UpA) and placed in a microwave digestion system (Milestone, Bergamo, Italy). Microwave assisted digestion was performed with a mineralization program for $15 \mathrm{~min}$ at $190^{\circ} \mathrm{C}$. Then, the vessels were cooled at room temperature, and the digestion mixtures were diluted at the final volume of $50.0 \mathrm{~mL}$ by adding ultrapure water (resistivity $18.2 \mathrm{M} \Omega \mathrm{cm}$ ) that was produced in-house using a purification system arium $\AA$ pro (Sartorius, Germany) (Ariano et al. 2019). $\mathrm{Pb}, \mathrm{Cr}$ and As concentrations in the digested samples were determined with an atomic absorption spectrometer equipped with a graphite furnace and a L'vov platform (GF-AAS, Analyst 600, Perkin-Elmer, Bonenseewerk, Germany). The LOQs were 0.020, 0.050 and $0.165 \mathrm{mg} \mathrm{kg}^{-1}$ for $\mathrm{Pb}, \mathrm{Cr}$ and As, respectively. 


\section{Quality assurance}

In the laboratory, appropriate quality assurance procedures were implemented in order to ensure the reliability of the results in accordance with the UNI/EN/ISO/IEC 17025 Standard (2005). Quality assurance and quality control (QA/ QC) of the methods were monitored through analysis of procedural blanks, duplicate samples and standard solutions. Standard solutions of analytes were prepared from certified stock solutions containing $\mathrm{Pb}, \mathrm{Cr}$, As (atomic spectroscopy standard, Perkin Elmer) and the PAH of interest. Concentrations for each set of samples were determined in the medium range of the calibration curve. The performance of the method was assessed through participation in interlaboratory studies organized by FAPAS (Food Analysis Performance Assessment Scheme, Sand Hutton, UK).

\section{Statistical analysis}

PAH concentrations were expressed in $\mu \mathrm{g} \mathrm{kg}^{-1}$ wet weight (ww) as sum of BaA, Cry, BaP and BbF (PAH4) and sum of BaA, Cry, BaP, BbF, BkF and DahA (PAH6) using mean \pm SEM (standard error of the mean). All metal concentrations were expressed in $\mathrm{mg} \mathrm{kg}^{-1}$ ww as mean \pm SEM.

Statistical significance of the influence of sampling sites (Castelvolturno Vs Napoli) has been tested using factorial analysis of variance. Furthermore, we apply ANOVA test to highlight differences between metals and $\mathrm{PAH}$ accumulation in the muscle of warty crabs and between the sampling areas. Multiple regressions have been used to discover statistical significance between metals and PAHs concentration and intrinsic variables (as length and width of specimens). One-sample KolmogorovSmirnov test confirmed normal distribution of our data. All our statistical analyses have been performed using MedCalc for Windows, version 18.11.3 (MedCalc Software, Ostend, Belgium). Significant value has been established at $\mathrm{p}<0.05$.

For statistical calculations, the contribution of the undetected PAHs was considered equal to zero; for the undetected metals, it was considered a contribution equal to $0.5 \mathrm{LOQ}$ (Menichini et al. 2004).

\section{Estimation of dietary intake and the carcinogenic risk}

In order to assess the exposition to $\mathrm{PAHs}, \mathrm{Cr}, \mathrm{As}$ and $\mathrm{Pb}$ of the population that regularly consumes warty crabs coming from the coasts of the Campania region and thus to evaluate the potential health risk resulting from it, the estimation of the weekly intakes were calculated using the levels of contaminants determined in the crab muscles. The calculations were carried out only for adults as they are considered the main consumers of these crustaceans. The estimated weekly intakes (EWIs) are calculated using the equation described by Lambiase et al. (2017) and reported below:

$$
E W I=\frac{(C \times W I)}{B W}
$$

where $\mathrm{C}$ is the mean concentrations of PAHs, $\mathrm{Cr}$, As and $\mathrm{Pb}$ determined in crab samples; $\mathrm{WI}$ is the human weekly intake of crabs; and BW is the body weight $(70 \mathrm{~kg})$. The EWIs were calculated using both the WI of $37.7 \mathrm{~g}$ week $^{-1}$ obtained by the Food and Agriculture Organization (FAO) (2013) and an estimated WI of one 100-g crustacean edible portion (Di Lena et al. 2018).

In addition, to assess the carcinogenic risk associated with the intake of PAHs, $\mathrm{Cr}$, As and $\mathrm{Pb}$ through the consumption of local crabs, the incremental lifetime cancer risk (ILCR) is also calculated using the equation described by Tiwari et al. (2017):

$I L C R=\frac{E D \times E F \times E D I \times S F \times C F}{A T}$

where $\mathrm{ED}$ is the exposure duration (83 year, Italian average life expectancy, (OECD/European Observatory on Health Systems and Policies 2017); EF is the exposure frequency (365 day yr ${ }^{-1}$ ); EDI is the estimated daily intake (ng kg ${ }^{-1}$ body weight (b.w.) day ${ }^{-1}$ ); SF is the oral cancer slope factor in $\mathrm{kg}$ day $\mathrm{mg}^{-1}: 7.3$ for BaP (Tiwari et al. 2017), $5 \times 10^{-1}$ for $\mathrm{Cr}$ (Aendo et al. 2019), 1.50 for As (Li et al. 2011) and $8.5 \times 10^{-3}$ for $\mathrm{Pb}$ (Aendo et al. 2019); $\mathrm{CF}$ is the conversion factor $(1.0 \times$ $\left.10^{-6} \mathrm{mg} \mathrm{ng}^{-1}\right)$; and AT is the average lifespan (30,295 days). The ILCR for PAH4 was calculated using the PAH concentration expressed in $\mathrm{BaP}$ equivalent obtained employing the toxic equivalent factors (TEFs) (Tiwari et al. 2017).

\section{Results}

\section{Polycyclic aromatic hydrocarbons}

PAH levels in crab muscle samples are reported in Table 1. The range concentrations of PAH4 and PAH6 were between < LOQ and $4.9 \mu \mathrm{g} \mathrm{kg}^{-1}$ ww for both the sums. Overall, the PAHs were detected in all samples except for seven crab muscles (25.0\% of the total) that showed BaA, Cry, BaP and BbF concentrations below the LOQs. BaP was detected only in $39.3 \%$ of the total warty crabs, and its concentration ranged between < LOQ and $0.5 \mu \mathrm{g} \mathrm{kg}^{-1}$ ww; BkF and DahA were detected in $25.0 \%$ and $10.7 \%$ of the total samples, respectively, and their range concentrations were $<\mathrm{LOQ}$ and $0.4 \mu \mathrm{g} \mathrm{kg}^{-1}$ ww for both substances. The most abundant PAHs were BbF and Cry that contributed to PAH4 with $35.1 \%$ (mean: $0.9 \mu \mathrm{g}$ $\mathrm{kg}^{-1} \mathrm{ww}$ ) and $21.6 \%$ (mean: $0.4 \mu \mathrm{g} \mathrm{kg}^{-1} \mathrm{ww}$ ), respectively. The levels of PAHs assessed in muscle of $E$. verrucosa varied between sampling sites (Fig. 2). Cry concentration was significantly higher in the crabs from Castelvolturno than those 
Table 1 PAH concentrations (range and mean \pm SEM) in E. verrucosa expressed in $\mu \mathrm{g} \mathrm{kg}^{-1} \mathrm{ww}$

\begin{tabular}{lll}
\hline & SITE A $(\mathrm{n}=13)$ & SITE B $(\mathrm{n}=15)$ \\
\hline $\mathrm{BaA}$ & $<$ LOQ-0.4 & $<$ LOQ-0.5 \\
& $(0.0 \pm 0.03)$ & $(0.1 \pm 0.05)$ \\
$\mathrm{Cry}$ & $<$ LOQ-1.8 & $<$ LOQ-1.2 \\
& $(0.7 \pm 0.15)$ & $(0.2 \pm 0.11)$ \\
$\mathrm{BbF}$ & $<$ LOQ-3.4 & $<$ LOQ-2.8 \\
& $(1.2 \pm 0.27)$ & $(0.6 \pm 0.24)$ \\
$\mathrm{BkF}$ & $<$ LOQ-0.4 & $<$ LOQ-0.4 \\
& $(0.1 \pm 0.04)$ & $(0.1 \pm 0.03)$ \\
$\mathrm{BaP}$ & $<$ LOQ-0.5 & $<$ LOQ-0.5 \\
& $(0.3 \pm 0.07)$ & $(0.1 \pm 0.05)$ \\
DahA & $<$ LOQ & $<$ LOQ-0.4 \\
& - & $(0.1 \pm 0.04)$ \\
PAH4 & $0.9-4.9$ & $<$ LOQ-4.1 \\
& $(2.3 \pm 0.33)$ & $(1.0 \pm 0.40)$ \\
PAH6 & $0.9-4.9$ & $<$ LOQ-4.5 \\
& $(2.4 \pm 0.36)$ & $(1.1 \pm 0.45)$ \\
\hline
\end{tabular}

from Naples ( $p<0.01)$; significant differences between site A and site $\mathrm{B}$ were also detected for $\mathrm{BaP}, \mathrm{PAH} 4$ and PAH6 concentrations $(\mathrm{p}<0.05)$.

The analysed individuals varied in length and width. The multiple regression analyses indicate that there was no correlation between size and concentration of all analysed PAHs ( $p$ $>0.05)$.

\section{Heavy metals}

Regarding the occurrence of metals in crab muscles, the results are reported in Table 2. Arsenic was the most abundant element detected in all samples; its concentration ranged from 0.985 to $14.555 \mathrm{mg} \mathrm{kg}^{-1}$ ww. As was followed by $\mathrm{Cr}$ (range: <
Table 2 Metal concentrations (range and mean \pm SEM) in E. verrucosa expressed in $\mathrm{mg} \mathrm{kg}^{-1} \mathrm{ww}$

\begin{tabular}{lll}
\hline & SITE A $(\mathrm{n}=13)$ & SITE B $(\mathrm{n}=15)$ \\
\hline $\mathrm{Pb}$ & $<$ LOQ-0.240 & $<$ LOQ-0.242 \\
& $(0.056 \pm 0.018)$ & $(0.078 \pm 0.016)$ \\
$\mathrm{As}$ & $1.093-10.243$ & $0.985-14.555$ \\
& $(3.098 \pm 0.850)$ & $(6.688 \pm 1.491)$ \\
$\mathrm{Cr}$ & $<\mathrm{LOQ}-3.216$ & $<$ LOQ -2.318 \\
& $(0.712 \pm 0.338)$ & $(0.257 \pm 0.150)$ \\
\hline
\end{tabular}

LOQ-3.216 $\mathrm{mg} \mathrm{kg}^{-1}$ ww) and $\mathrm{Pb}$ (range: < LOQ-0.242 mg $\mathrm{kg}^{-1}$ ww). Contrary to PAHs, there were no statistical differences between metals concentration and sampling sites $(\mathrm{p}>$ 0.05 ) (Fig. 3). The multiple regression analyses indicate that there was no correlation between size and concentration of all analysed metals $(\mathrm{p}>0.05)$.

\section{Discussion}

\section{Polycyclic aromatic hydrocarbons}

The crab muscle samples analysed in the current study showed low concentrations of each PAH investigated. The Commission Regulation (EU) 835/2011 2011 does not fix $\mathrm{BaP}$ and PAH4 MLs for crabs and in general for all crustaceans; therefore, it was not possible to assess whether the contamination levels determined in the samples were compliant with the EU Regulation. Nevertheless, the $\mathrm{BaP}$ and PAH4 concentrations reported herein resulted lower than the MLs set for smoked crabs and for other types of foodstuffs (Commission Regulation (EU) 835/2011 2011).

In addition to lacking of European and national regulations as regard PAH contamination in these marine organisms, there are also very few data available on this issue in literature
Fig. 2 PAH concentrations in

E. verrucosa depending on sampling sites: A Castelvolturno $(\mathrm{n}=13)$ vs B Naples $(\mathrm{n}=15)$.

Vertical bars represent average concentration $\left(\mu \mathrm{g} \mathrm{kg}^{-1} \mathrm{ww}\right) \pm$ SEM. Probability levels for significant differences: $\mathrm{p}<0.01$ $(* *) ; \mathrm{p}<0.05(*)$

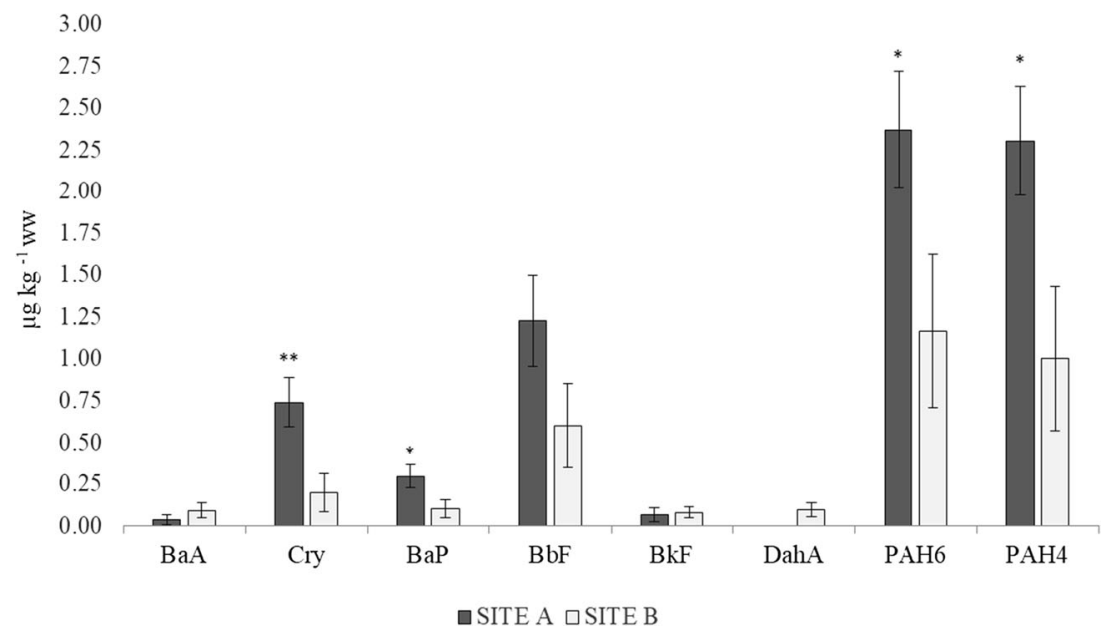




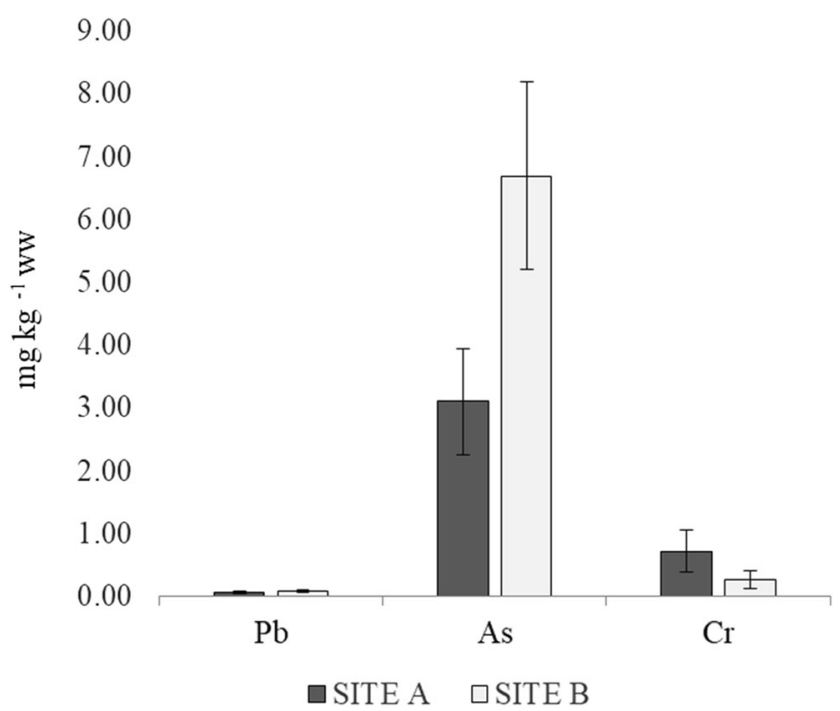

Fig. 3 Heavy metal concentrations in E. verrucosa depending on sampling sites: A Castelvolturno $(n=13)$ vs B Naples $(n=15)$. Vertical bars represent average concentration $\left(\mathrm{mg} \mathrm{kg}^{-1}\right.$ ww) \pm SEM. Probability levels for significant differences: $p<0.01(* *) ; p<0.05$ (*)

which are also often reported in different way (dry or wet weight) making the comparisons difficult. Nevertheless, in order to assess the PAH contamination level of the crabs coming from the northern coast of Campania region in relation to crustaceans coming from other marine areas and hence the potential health risk of the consumption of this seafood, the results reported in this study were compared to the data described by few authors on crabs coming from other coastal areas. Abdolahpur Monikh et al. (2014) described $\mathrm{BaP}$ concentrations in muscles of Portunus pelagicus, sampled in the Persian Gulf that ranged from 170 to $956 \mathrm{ng} \mathrm{g}^{-1}$ on dry weight (dw) (mean: $200 \mathrm{ng} \mathrm{g}^{-1} \mathrm{dw}$ ). Considering that crustaceans have an average water content of about $80 \%$ (Vinogradov 2018), the mean BaP concentration expressed on wet weight became $40 \mathrm{ng} \mathrm{g}^{-1} \mathrm{ww}$, and therefore it was much higher than the mean values of $\mathrm{BaP}$ found in the present study. Zhang et al. (2020), in a study on PAH bioaccumulation in marine organisms from South Yellow Sea in China, determined in crab samples concentrations (sum of $16 \mathrm{PAHs}$ ) that ranged from 119.11 to $223.34 \mathrm{ng} \mathrm{g}^{-1} \mathrm{dw}$ resulting higher than our results.

Moreover, they described that among benthic and benthivorous organisms, crabs showed lower PAH concentrations than shrimps and demersal fish. The mean PAH concentrations found in this study resulted instead higher than those found in crabs (Callinectes amnicola) from Atlas Cove (Nigeria) analysed by Olayinka et al. (2019) who determined concentrations of the PAH6 below the detection limits in all samples. Perugini et al. (2007), in Norway lobster from Central Adriatic Sea, also showed Cry and BbF concentrations below the detection limit, while the $\mathrm{BaA}$ and $\mathrm{BkF}$ were slightly higher than the concentrations detected in this study. Therefore, the overall PAH level reported herein resulted comparable or lower than those described in other marine areas indicating a low risk for human health. In order to obtain more data on the bioaccumulation of PAHs in crustaceans from the coasts of the Campania region and the health risks for the population that consumes this food, the concentrations found in this study were compared with those reported by other authors that investigated this marine area. From comparing, the PAH levels detected in warty crabs resulted lower than the levels found in other fish and seafood species (Fasano et al. 2018; Fiorito et al. 2019).

The low levels of PAHs detected in the present study suggest that the exposure to these contaminants of the population of this area that consumes crabs and in general crustaceans and the consequent health risk are also low. All these findings led to suppose that the PAH concentrations found in the edible parts of the crabs can be considered at baseline levels.

It was interesting to find that the PAH concentrations determined in the crab muscles from Castelvolturno were significantly higher than those found in the animals from Naples; this difference in concentrations could be attributed to the presence of the Volturno river that flows into the Tyrrhenian Sea at Castelvolturno.

The Volturno is the longest Southern Italian river which crosses densely populated areas, such as the province of Caserta, and that collects pollutants mainly from zootechnical and agricultural activities, handcrafts and industries (Isidori et al. 2004; Zuzolo et al., 2016).

Otherwise, the source of contamination of the Gulf of Naples is mainly represented by maritime transports, fishing and coastal tourism (Esposito et al. 2017). Regarding the difference in PAH concentrations in relation to the size of crabs, it was not statistically significant in agreement to the results showed by other authors (Perugini et al. 2007).

As a concern, BkF and DahA were detected in crab muscles at levels comparable to PAHs included in Commission Regulation (EU) No 835/2011. BkF and DahA are classified by the IARC as possible and probable carcinogenic to humans, respectively.

On the basis of this classification, the EFSA Panel on Contaminants in the Food Chain (CONTAM Panel) included also these two substances in the group of eight PAHs that are considered the only indicators of the carcinogenic potency of these contaminants in food (EFSA (European Food Safety Authority) 2008). Therefore, considering the BkF and DahA levels described herein in crabs, it may be recommended to develop new food safety plans to monitor also these two substances.

\section{Heavy metals}

The heavy metal analysis carried out in this study showed low levels of $\mathrm{Pb}$ and $\mathrm{Cr}$ but a high presence of As in crab muscles samples. Interestingly and contrary to what was observed for 
PAHs, the heavy metal levels found in the crabs were higher than those found in fish and mussels coming from the same marine area (Fasano et al. 2018) showing that these organisms, as also described by other authors, can bioaccumulate toxic elements in their tissues when they live in polluted environment (Perry et al. 2015; Karar et al. 2019; Bordon et al. 2020). Pb was detected at low levels in the crabs from both sampling sites resulting below MLs established in muscle meat of crustaceans $\left(0.5 \mu \mathrm{g} \mathrm{g}^{-1} \mathrm{ww}\right)$ by the Commission Regulation (EC) No 1881/2006 and its amendment (Commission Regulation (EU) No 420/2011, 2011). Concerning $\mathrm{Cr}$ and As, although some forms of these elements are recognized as carcinogenic to humans (Group 1) by the IARC (IARC, 1973, 1980, 2012), there are no MLs laid down for food by the European Commission.

Overall, As was the most abundant element detected in warty crab muscles followed by $\mathrm{Cr}$ and $\mathrm{Pb}$. Comparison of the studies carried out by other authors showed that the As concentrations assessed in warty crabs from northern coast of Campania region resulted higher than those measured in the muscle of Eriphia verrucosa and Rapana venosa from Turkey (Levent and Öztekin 2016), in the muscle of fiddler crab of Uca tangeri species (mean: $1.76 \mu \mathrm{g} \mathrm{g}^{-1}$ ) collected from Spain (Suner et al. 1999) and also in the edible muscle of warty crab from the Black Sea that had As concentrations ranging from $1.34 \mu \mathrm{g} \mathrm{g}^{-1}$ to $2.43 \mu \mathrm{g} \mathrm{g}^{-1} \mathrm{ww}$ (Durmus et al. 2018). It has been reported that benthonic species that feed close to the coasts may bioaccumulate higher As levels than pelagic ones. In fact, being As naturally presents in rocks, marine environment near the coasts has an abundant amount of this element (Ramos-Miras 2019). In particular, Campania region is a territory characterised by high background levels of As of volcanic origin; in fact, high concentrations of this metal were found in the pyroclastic deposits in the NW and SE sectors of the region, including the coastal areas, as also in the Volturno River plain (Albanese et al. 2007; Petrik et al. 2018). On the basis of this information, it was possible to hypothesize that the As levels found in the crabs analysed herein derived from natural sources due to the large volcanic area present in the region.

Moreover, it is important considered that of the total As (tAs) amount only the inorganic As (iAs) rate is harmful to human health. According to the data available in literature and the EFSA opinion, in fish and in general all seafood, the tAs include mainly arsenobetaine, and the iAs rate varies depending on the species of fish or seafood (EFSA, 2014). However, Cubadda et al. (2016), in a study on the dietary exposure of the Italian population to iAs, found that crustaceans and molluses are one of the food group with the highest iAs concentration (28.3 $\left.\mathrm{ng} \mathrm{g}^{-1} \mathrm{ww}\right)$.

Concerning the other two heavy metals measured, the $\mathrm{Pb}$ concentrations found in the muscle of E. verrucosa in Naples and Castelvolturno sites were approximatively comparable than those measured in the muscle of warty crab from Turkey (Levent and Öztekin 2016) and from Adriatic Sea (Zotti et al. 2016). Instead, the levels of $\mathrm{Pb}$ resulted lower than the concentrations detected in muscles of Rapana venosa ( 0.1 to $0.7 \mu \mathrm{g} \mathrm{g}^{-1}$ ) analysed by Mülayim and Balkıs (2015) and in the edible muscle of warty crab $\left(0.13 \mu \mathrm{g} \mathrm{g}^{-1}\right.$ to $0.36 \mu \mathrm{g} \mathrm{g}^{-1}$ ww) analysed by Durmus et al. (2018) both collected from the Black Sea. The $\mathrm{Pb}$ levels assessed in this study resulted also lower than the levels found in the edible muscle $\left(0.10 \mu \mathrm{g} \mathrm{g}^{-1}\right)$ of Chinese mitten crabs (Eriocheir sinensis) from rivers and lakes of Netherlands (Hoogenboom et al. 2015), in muscles of the blue crab $\left(1.08 \pm 0.56 \mathrm{mg} \mathrm{kg}^{-1}\right)$ collected from the northern Bay of Bengal (Karar et al. 2019) and in muscles of the red crab from the Gulf of Mexico (Perry et al. 2015).

For $\mathrm{Cr}$, the levels detected in the present study were comparable to those found in muscle of Rapana venosa ( $0.47 \pm$ $0.01 \mu \mathrm{g} \mathrm{g}^{-1}$ ) from the Black Sea (Topcuoğlu et al. 2002) and in muscles of the blue crabs $\left(0.68 \pm 0.50 \mathrm{mg} \mathrm{kg}^{-1}\right)$ collected from the northern Bay of Bengal (Karar et al. 2019), while the $\mathrm{Cr}$ levels resulted higher than those found in muscle of Rapana venosa ( 0.1 to $\left.0.2 \mu \mathrm{g} \mathrm{g}^{-1}\right)$ from the Black Sea analysed by Mülayim and Balkıs (2015) and in muscle of warty crab from Adriatic Sea (Zotti et al. 2016). Moreover, it has been reported by many authors that the bioaccumulation of toxic metals in crabs, and in general in all marine animals, depends on several physiological and biometric factors among which the body size is recognized as an important parameter (Pinheiro et al. 2012; Knutsen et al. 2018; Wiech et al. 2020). In the current study, the statistical analysis showed that the heavy metal levels were not statistically correlated to the size of the crabs ( $p>0.05$ ), suggesting that these parameters have a minor effect on metals accumulation in subjects inside the size range considered in this study. In fact, the length and width of warty crabs carapace in the present study ranged between 3.8 and $6.0 \mathrm{~cm}$ (mean value: $4.9 \mathrm{~cm}$ ) and 5.0 and $8.0 \mathrm{~cm}$ (mean value: $6.2 \mathrm{~cm}$ ), respectively. It has been described that the metal bioaccumulation is strongly influenced by metabolism in fish (Canli and Atli 2003). Hence, same authors have been suggested that the negative correlation is probably due to a faster metabolism rate of the smaller animals, which correspond to the younger specimens, than the older ones (Sofoulaki et al. 2018). Therefore, these processes could lead to a dilution of the contaminant concentration with growth. However, it has been observed that the negative correlation between metal concentrations and body size occurs when the marine pollution is at low levels; for high levels of pollution, instead, a positive correlation has been described (Sofoulaki et al. 2018).

\section{Health risk assessment}

The EWI calculated for BaP, PAH4, Cr, As and Pb that occurs through the consumption of crabs from the coasts of the Campania region are showed in Table 3. As regard PAHs, a 
Table 3 Estimated weekly intake (EWI) of BaP, PAH4, Cr, As and $\mathrm{Pb}$ calculated using both WIs (37.7 and $\left.100 \mathrm{~g} \mathrm{week}^{-1}\right)$ and expressed in $\mu \mathrm{g}$ $\mathrm{kg}^{-1}$ b.w. week ${ }^{-1}$

\begin{tabular}{llllll}
\hline \multicolumn{1}{c}{$\mathrm{BaP}$} & PAH4 & $\mathrm{Cr}$ & $\mathrm{As}$ & $\mathrm{Pb}$ \\
\hline EWI (WI 37.7 $\left.\mathrm{g} \mathrm{week}^{-1}\right)^{\mathrm{a}}$ & & & & \\
Min & $\mathrm{nc}$ & $\mathrm{nc}$ & 0.0135 & 0.5305 & 0.0054 \\
Max & 0.0003 & 0.0026 & 1.7320 & 7.8389 & 0.1303 \\
Mean & 0.0001 & 0.0009 & 0.2523 & 2.7041 & 0.0366 \\
Median & $\mathrm{nc}$ & 0.0007 & 0.0439 & 0.9193 & 0.0304 \\
EWI (WI 100 $\left.\mathrm{g} \mathrm{week}^{-1}\right)^{\mathrm{b}}$ & & & & \\
Min & $\mathrm{nc}$ & $\mathrm{nc}$ & 0.0357 & 1.4071 & 0.0143 \\
Max & 0.0008 & 0.0070 & 4.5943 & 20.7929 & 0.3457 \\
Mean & 0.0003 & 0.0023 & 0.6691 & 7.1728 & 0.0970 \\
Median & $\mathrm{nc}$ & 0.0019 & 0.1164 & 2.4386 & 0.0807 \\
\hline
\end{tabular}

${ }^{\mathrm{a}}$ WI obtained from FAO, 2013

${ }^{\mathrm{b}}$ WI obtained from Di Lena et al. 2018

$n c$ Not calculable

human tolerable weekly intake has not been fixed. The EFSA Panel on Contaminants in the Food Chain (CONTAM) in its Scientific Opinion regarding polycyclic aromatic hydrocarbons in food (EFSA (European Food Safety Authority) 2008) reported median values of consumer exposure to $\mathrm{BaP}$ and PAH4 for the food category fish and fishery products of 21 and $170 \mathrm{ng} \mathrm{day}^{-1}$, respectively. The EWIs calculated using the values reported by EFSA (European Food Safety Authority) 2008assuming a body weight of $70 \mathrm{~kg}(2.1 \mathrm{ng}$ $\mathrm{kg}^{-1}$ b.w. per week for BaP and $17 \mathrm{ng} \mathrm{kg}^{-1}$ b.w. per week for PAH4) were higher than the EWIs calculated with the concentrations found in the present study. This finding showed that the exposure of the population to these contaminants through the consumption of local crabs involves a low health risk. Moreover, for human exposure risk characterization, in its opinion, EFSA used the bench mark dose lower confidence limit $\left(\mathrm{BMDL}_{10}\right)$ for a $10 \%$ increase in the number of tumour in animals (EFSA (European Food Safety Authority) 2008). The BMDL $_{10}$ derived by EFSA (European Food Safety Authority) (2008) were 0.07 and $0.34 \mathrm{mg} \mathrm{kg}^{-1}$ b.w. day ${ }^{-1}$ for $\mathrm{BaP}$ and $\mathrm{PAH} 4$, respectively. Also considering these values, the consumption of local crabs resulting safe for human health. Regarding $\mathrm{Cr}$, As and $\mathrm{Pb}$, the CONTAM Panel established a TDI only for $\mathrm{Cr}$ (III), supposing that all chromium in food is in this chemical form, that is $0.3 \mathrm{mg} \mathrm{kg}^{-1}$ b.w. per day $(2.1 \mathrm{mg}$ $\mathrm{kg}^{-1}$ b.w. per week), resulting higher than the value calculated herein. For As and $\mathrm{Pb}$, the EFSA Panel has not been set any TDI or TWI values. Precisely, the Joint FAO/WHO Expert Committee on Food Additives (JECFA) fixed a provisional tolerable weekly intake (PTWI) of $15 \mu \mathrm{g} \mathrm{kg}^{-1}$ b.w. per week for iAs and $25 \mu \mathrm{g} \mathrm{kg}^{-1}$ b.w. per week for $\mathrm{Pb}$. These values were considered no longer suitable by the EFSA Panel that established for iAs a BMDL $\mathrm{BD}_{01}$ between 0.3 and $8 \mu \mathrm{g} \mathrm{kg}^{-1}$ b.w. per day for an increased risk of cancer of the lung, skin and bladder, as well as skin lesions (EFSA, 2014) and for Pb a BMDL $_{01}$ of $1.50 \mu \mathrm{g} \mathrm{kg}^{-1}$ b.w. per day for an increased risk of cardiovascular effects and nephrotoxicity in adults (EFSA, 2012). Hence, as for the PAHs, the EWI values calculated for the metals showed a low exposure to these toxic pollutants for the population that consumes crustaceans.

Regarding the carcinogenic risk associated with the $\mathrm{BaP}$, $\mathrm{PAH} 4, \mathrm{Cr}$, As and $\mathrm{Pb}$ intakes through the consumption of crabs, the ILCRs calculated are reported in Table 4. For the carcinogenic risk assessment, it was set a threshold of $1.0 \mathrm{x}$ $10^{-6}$ which means there is one in a million chances for an individual to develop cancer over a lifetime as a result of exposure to a carcinogen (Tiwari et al. 2017; Aendo et al. 2019); at this level, the cancer risk is considered negligible. The risk becomes serious when the ILCR exceeds the threshold of $1.0 \times 10^{-4}$ (Aendo et al. 2019).

The ILCRs calculated in this study were in the range between $4.46 \times 10^{-3}$ and $6.53 \times 10^{-9}$. The highest ILCR values, which exceed the threshold of $1.0 \times 10^{-4}$, were obtained for As and for $\mathrm{Cr}$, when the ILCR was calculated using the maximum $\mathrm{Cr}$ concentration found in the crabs, indicating that for these elements, there is a potentially risk for human health. However, these results were obtained using the total concentration of As and $\mathrm{Cr}$ and not the rates recognised as carcinogenic, which are iAs and $\mathrm{Cr}(\mathrm{VI})$; hence, due to the lack of information, it was impossible to make toxicological discussions.

Table 4 Incremental lifetime cancer risk (ILCR) of BaP, PAH4, Cr, As and $\mathrm{Pb}$ calculated using both daily intakes (DIs, 5.38 and $14.28 \mathrm{~g} \mathrm{day}^{-1}$ )

\begin{tabular}{|c|c|c|c|c|c|}
\hline & $\mathrm{BaP}$ & $\mathrm{PAH} 4^{\mathrm{c}}$ & $\mathrm{Cr}$ & As & $\mathrm{Pb}$ \\
\hline \multicolumn{6}{|c|}{ ILCR (DI $\left.5.38 \mathrm{~g} \mathrm{day}^{-1}\right)^{\mathrm{a}}$} \\
\hline Min & $\mathrm{nc}$ & $\mathrm{nc}$ & $9.61 \times 10^{-7}$ & $1.14 \times 10^{-4}$ & $6.53 \times 10^{-9}$ \\
\hline $\operatorname{Max}$ & $3.03 \times 10^{-7}$ & $4.91 \times 10^{-7}$ & $1.24 \times 10^{-4}$ & $1.68 \times 10^{-3}$ & $1.58 \times 10^{-7}$ \\
\hline Mean & $1.06 \times 10^{-7}$ & $1.62 \times 10^{-7}$ & $1.80 \times 10^{-5}$ & $5.79 \times 10^{-4}$ & $4.44 \times 10^{-8}$ \\
\hline Median & nc & $5.88 \times 10^{-8}$ & $3.13 \times 10^{-6}$ & $1.97 \times 10^{-4}$ & $3.69 \times 10^{-8}$ \\
\hline \multicolumn{6}{|c|}{ ILRC (DI $\left.14.28 \mathrm{~g} \mathrm{day}^{-1}\right)^{\mathrm{b}}$} \\
\hline Min & $\mathrm{nc}$ & $\mathrm{nc}$ & $2.55 \times 10^{-6}$ & $3.02 \times 10^{-4}$ & $1.74 \times 10^{-8}$ \\
\hline $\operatorname{Max}$ & $8.05 \times 10^{-7}$ & $1.30 \times 10^{-6}$ & $3.28 \times 10^{-4}$ & $4.46 \times 10^{-3}$ & $4.20 \times 10^{-7}$ \\
\hline Mean & $2.82 \times 10^{-7}$ & $4.30 \times 10^{-7}$ & $4.78 \times 10^{-5}$ & $1.54 \times 10^{-3}$ & $1.18 \times 10^{-7}$ \\
\hline Median & nc & $1.56 \times 10^{-7}$ & $8.32 \times 10^{-6}$ & $5.23 \times 10^{-4}$ & $9.81 \times 10^{-8}$ \\
\hline \multicolumn{6}{|c|}{${ }^{\mathrm{a}}$ DI obtained from FAO, 2013} \\
\hline \multicolumn{6}{|c|}{${ }^{\mathrm{b}}$ DI obtained from Di Lena et al. 2018} \\
\hline \multicolumn{6}{|c|}{$\begin{array}{l}{ }^{\mathrm{c}} \text { The PAH concentrations used for the ILCR calculations were expressed } \\
\text { in BaP equivalent }\end{array}$} \\
\hline
\end{tabular}




\section{Conclusions}

This study assesses the PAH and heavy metal levels in E. verrucosa from the northern coast of the Campania region improving the data regarding dangerous chemical compounds in this traditional Mediterranean crustacean. The results suggested a limited contamination of $\mathrm{Pb}, \mathrm{Cr}$ and $\mathrm{PAHs}$ in the study areas indicating a low risk for human consumption. In fact, the EWIs and ILCRs calculated for these carcinogens were compliant with the thresholds considered safe for human health. Moreover, in addition to the four PAHs included in the Commission Regulation (EU) No 835/2011, the analysis showed the occurrence also of BkF and DahA in crab muscles. Considering that these two substances are recognized as possible and probable carcinogenic to humans respectively, it would be necessary to put more careful attention to official controls and monitoring on toxicological investigation including also these two PAHs to assure public health. Contrariwise, higher As concentrations that had probably a natural origin were found in muscle of warty crabs. The ILCRs calculated for As exceeded the acceptable level of cancer risk indicating a potentially threat for human health. These findings should be thoroughly studied in order to understand the bioaccumulation mechanisms and to identify anthropogenic sources of As pollution in the these marine areas in addition to natural ones.

Author contribution Conceptualization: LS and ME. Data curation: SL, AA, FPS, MS, SV, ME and LS. Formal analysis: SL, AA, FPS, SV and MS. Investigation: SL, AA, ME and LS. Methodology: AA, FPS, ME and LS. Project administration: ME and LS. Resources: ME and LS. Supervision: ME and LS. Validation: ME and LS. Visualization: ME and LS. Writing, original draft: SL and AA. Writing, review and editing: SL, AA, ME and LS. All authors read and approved the final manuscript..

Funding Open access funding provided by Università degli Studi di Napoli Federico II within the CRUI-CARE Agreement.

Availability of data and materials The datasets used and/or analysed during the current study are available from the corresponding author on reasonable request.

\section{Declarations}

Ethics approval and consent to participate Not applicable.

\section{Consent for publication Not applicable.}

Competing interests The authors declare no competing Dietary exposure to inorganic arsenic in the European populationinterests.

Open Access This article is licensed under a Creative Commons Attribution 4.0 International License, which permits use, sharing, adaptation, distribution and reproduction in any medium or format, as long as you give appropriate credit to the original author(s) and the source, provide a link to the Creative Commons licence, and indicate if changes were made. The images or other third party material in this article are included in the article's Creative Commons licence, unless indicated otherwise in a credit line to the material. If material is not included in the article's Creative Commons licence and your intended use is not permitted by statutory regulation or exceeds the permitted use, you will need to obtain permission directly from the copyright holder. To view a copy of this licence, visit http://creativecommons.org/licenses/by/4.0/.

\section{References}

Abdolahpur Monikh F, Hosseini M, Rahmanpour S (2014) The effect of size and sex on PCB and PAH concentrations in crab Portunus pelagicus. Environ. Monit. Assess. 186:1575-1582. https://doi. org/10.1007/s10661-013-3475-x

Aendo P, Thongyuan S, Songserm T, Tulayakul P (2019) Carcinogenic and non-carcinogenic risk assessment of heavy metals contamination in duck eggs and meat as a warning scenario in Thailand. Sci Total Environ. 689:215-222. https://doi.org/10.1016/j.scitotenv. 2019.06 .414

Albanese S, De Vivo B, Lima A, Cicchella D (2007) Geochemical background and baseline values of toxic elements in stream sediments of Campania region (Italy). J. Geochem. Explor. 93:21-34. https://doi. org/10.1016/j.gexplo.2006.07.006

Ariano A, Lo Voi A, D'Ambola M, Marrone R, Cacace D, Severino L (2015) Levels of cadmium in white and brown meat of warty crab (Eriphia verrucosa). J. Food Prot. 78:2253-2256. https://doi.org/10. 4315/0362-028X.JFP-15-214

Ariano A, Marrone R, Andreini R, Smaldone G, Velotto S, Montagnaro S, Anastasio A, Severino L (2019) Metal concentration in muscle and digestive gland of common octopus (Octopus vulgaris) from two coastal site in Southern Tyrrhenian Sea (Italy). Molecules 24: 2401. https://doi.org/10.3390/molecules24132401

Bordon IC, Joviano WR, de Medeiros AMZ, de Campos BG, de Araujo GS, Gusso-Choueri PK, de Freitas Preto M, Teixeira Favaro DI, de Souza Abessa DM (2020) Heavy metals in tissues of blue crabs Callinectes danae from a subtropical protected estuary influenced by mining residues. Bull. Environ. Contam. Toxicol. 104:418-422. https://doi.org/10.1007/s00128-020-02815-y

Canli M, Atli G (2003) The relationships between heavy metal (Cd, Cr, $\mathrm{Cu}, \mathrm{Fe}, \mathrm{Pb}, \mathrm{Zn}$ ) levels and the size of six Mediterranean fish species. Environ. Pollut. 121:129-136. https://doi.org/10.1016/s02697491(02)00194-x

Cappello T, Giannetto A, Parrino V, De Marco G, Mauceri A, Maisano M (2018) Food safety using NMR-based metabolomics: assessment of the Atlantic bluefin tuna, Thunnus thynnus, from the Mediterranean Sea. Food Chem. Toxicol. 115:391-397. https://doi.org/10.1016/j. fct.2018.03.038

Cederholm T (2017) Fish consumption and omega-3 fatty acid supplementation for prevention or treatment of cognitive decline, dementia or Alzheimer's disease in older adults-any news? Curr. Opin. Clin. Nutr. Metab. Care 20:104-109. https://doi.org/10.1097/MCO. 0000000000000350

Commission Regulation (EC) 1881/2006 (2006) Commission Regulation (EC) No. 1881/2006 of 19 December 2006 setting maximum levels for certain contaminants in foodstuffs. Off. J. Eur. Union L. 364:524

Commission Regulation (EC) 333/2007 (2007) Commission Regulation (EC) No 333/2007of 28 March 2007 laying down the methods of sampling and analysis for the official control of the levels of lead, cadmium, mercury, inorganic tin, 3-MCPD and benzo(a)pyrene in foodstuffs. Off. J. Eur. Union L. 88:29-38

Commission Regulation (EU) 835/2011 (2011) Commission Regulation (EU) No. 835/2011 of 19 August 2011 amending Regulation (EC) 
No 1881/2006 as regards maximum levels for polycyclic aromatic hydrocarbons in foodstuffs. Off. J. Eur. Union L. 215:4-8

Commission Regulation (EU) 836/2011, 2011. Commission Regulation (EU) No. 836/2011 of 19 August 2011 amending Regulation (EC) No 333/2007 laying down the methods of sampling and analysis for the official control of the levels of lead, cadmium, mercury, inorganic tin, 3-MCPD and benzo(a)pyrene in foodstuffs. Off. J. Eur. Union L. 215, 9-16.

Cubadda F, D'Amato M, Aureli F, Raggi A, Mantovani A (2016) Dietary exposure of the Italian population to inorganic arsenic: the 20122014 Total Diet Study. Food Chem. Toxicol. 98:148-158. https:// doi.org/10.1016/j.fct.2016.10.015

Di Lena G, Casini I, Caproni R, Orban E (2018) Total mercury levels in crustacean species from Italian fishery. Food Addit Contam Part B Surveill. 11:175-182. https://doi.org/10.1080/19393210.2018. 1450302

Durmus M, Ayas D, Aydin M, Kosker AR, Ucar Y, Ozogul Y (2018) The effects of sex and seasonality on the metal levels of warty crab (Eriphia verrucosa) in the Black Sea. J. Aquat. Food Prod. Technol. 27:749-758. https://doi.org/10.1080/10498850.2018. 1485196

EFSA (European Food Safety Authority) (2008) Polycyclic aromatic hydrocarbons in food. Scientific Opinion of the Panel on Contaminants in the Food Chain. EFSA J. 724:1-114. https://doi.org/10.2903/j. efsa. 2008.724

Esposito M, Perugini M, Lambiase S, Conte A, Baldi L, Amorena M (2017) Seasonal trend of PAHs concentrations in farmed mussels from the coastal areas of the Naples. Italy. Bull. Environ. Contam. Toxicol. 99:333-337. https://doi.org/10.1007/s00128-017-2141-3

Fasano E, Arnese A, Esposito F, Albano L, Masucci A, Capelli C, Cirillo T, Nardone A (2018) Evaluation of the impact of anthropogenic activities on arsenic, cadmium, chromium, mercury, lead, and polycyclic aromatic hydrocarbon levels in seafood from the Gulf of Naples. Italy. J Environ Sci Health A Tox Hazard Subst Environ Eng. 53:786-792. https://doi.org/10.1080/10934529.2018.1445075

Fiorito F, Amoroso MG, Lambiase S, Serpe FP, Bruno T, Scaramuzzo A, Maglio P, Fusco G, Esposito M (2019) A relationship between environmental pollutants and enteric viruses in mussels (Mytilus galloprovincialis). Environ Res. 169:156-162. https://doi.org/10. 1016/j.envres.2018.11.001

Ferrante M, Zanghì G, Cristaldi A, Copat C, Grasso A, Fiore M, Conti GO (2018) PAHs in seafood from the Mediterranean Sea: an exposure risk assessment. Food Chem. Toxicol. 115:385-390. https:// doi.org/10.1016/j.fct.2018.03.024

Food and Agriculture Organization (FAO), 2013. FAOSTAT food supply: livestock and fish primary equivalent. [Internet]. [accessed 2020 October 26]. Available from: http://www.fao.org/faostat/en/\#data/ CL.

Habibullah-Al-Mamun M, Ahmed MK, Islam MS, Tokumura M, Masunaga S (2019) Distribution of polycyclic aromatic hydrocarbons (PAHs) in commonly consumed seafood from coastal areas of Bangladesh and associated human health implications. Environ. Geochem. Health 41:1105-1121. https://doi.org/10.1007/s10653018-0202-0

Hoogenboom RLAP, Kotterman MJJ, van Nieuwenhuizen MH, van der Lee MK, Mennes WC, Jeurissen SMF, van Leeuwen SPJ (2015) Dioxins, PCBs and heavy metals in Chinese mitten crabs from Dutch rivers and lakes. Chemosphere 123:1-8. https://doi.org/10. 1016/j.chemosphere.2014.10.055

IARC (International Agency for Research on Cancer) (1973) Some inorganic and organometallic compounds. IARC Monographs on the Evaluation of Carcinogenic Risks to Humans, vol 2. Lyon, France, $182 \mathrm{pp}$

IARC (International Agency for Research on Cancer) (1980) Some metals and metallic compounds. IARC Monographs on the
Evaluation of Carcinogenic Risk of Chemicals to Humans, vol 23. Lyon, France, $432 \mathrm{pp}$

IARC (International Agency for Research on Cancer) (2012) Monographs on the evaluation of carcinogenic risks to humans. In: A Review of Human Carcinogens: Arsenic, Metals, Fibres, and Dusts, vol 100. C. Lyon, France, 527 pp

IARC (International Agency for Research on Cancer), 2013. Monographs on the evaluation of carcinogenic risks to humans. Bitumens and Bitumen Emissions, and Some N-and S-Heterocyclic Polycyclic Aromatic Hydrocarbons, vol. 103. Lyon, France. 361 pp.

Isidori M, Lavorgna M, Nardelli A, Parrella A (2004) Integrated environmental assessment of Volturno River in South Italy. Sci. Total Environ. 327:123-134. https://doi.org/10.1016/j.scitotenv.2004.01. 021

Karar S, Hazra S, Das S (2019) Assessment of the heavy metal accumulation in the blue swimmer crab (Portunus pelagicus), northern Bay of Bengal: role of salinity. Mar. Pollut. Bull. 143:101-108. https:// doi.org/10.1016/j.marpolbul.2019.04.033

Knutsen H, Wiech M, Duinker A, Maage A (2018) Cadmium in the shore crab Carcinus maenas along the Norwegian coast: geographical and seasonal variation and correlation to physiological parameters. Environ. Monit. Assess. 190:253. https://doi.org/10.1007/s10661018-6606-6

Lambiase S, Serpe FP, Cavallo S, Rosato G, Baldi L, Neri B, Esposito M (2017) Occurrence of polychlorinated dibenzo-p-dioxins (PCDDs), dibenzofurans (PCDFs) and polychlorinated biphenyls (PCBs) in eggs from free-range hens in Campania (southern Italy) and risk evaluation. Food Addit Contam A. 34:56-64. https://doi.org/10. 1080/19440049.2016.1260167

Levent BAT, Öztekin HC (2016) Heavy metals in Mytilus galloprovincialis. Rapana venosa and Eriphia verrucosa from the Black Sea coasts of Turkey as bioindicators of pollution. Walailak J. Sci. \& Tech. 13:715-728

Li G, Sun GX, Williams PN, Nunes L, Zhu YG (2011) Inorganic arsenic in Chinese food and its cancer risk. Environ Int. 37:1219-1225. https://doi.org/10.1016/j.envint.2011.05.007

Lundstedt S, White PA, Lemieux CL, Lynes KD, Lambert IB, Öberg L, Tysklind M (2007) Sources, fate, and toxic hazards of oxygenated polycyclic aromatic hydrocarbons (PAHs) at PAH-contaminated sites. AMBIO 36:475-486. https://doi.org/10.1579/00447447(2007)36[475:sfatho]2.0.co;2

Maulvault AL, Anacleto P, Barbosa V, Sloth JJ, Rasmussen RR, Tediosi A, Fernandez-Tejedor M, van den Heuvel FH, Kotterman M, Marques A (2015) Toxic elements and speciation in seafood samples from different contaminated sites in Europe. Environ. Res. 143: 72-81. https://doi.org/10.1016/j.envres.2015.09.016

Menichini E, Viviano G e il Gruppo di lavoro Istituto Superiore di Sanità "Metodiche per il rilevamento delle emissioni in atmosfera da impianti industriali". Trattamento dei dati inferiori al limite di rivelabilità nel calcolo dei risultati analitici. Roma: Istituto Superiore di Sanità; 2004. (Rapporti ISTISAN 04/15).

Molin M, Ulven SM, Meltzer HM, Alexander J (2015) Arsenic in the human food chain, biotransformation and toxicology-review focusing on seafood arsenic. J. Trace Elem. Med. Biol. 31:249-259. https://doi.org/10.1016/j.jtemb.2015.01.010

Mülayim A, Balkıs H (2015) Toxic metal ( $\mathrm{Pb}, \mathrm{Cd}, \mathrm{Cr}$, and $\mathrm{Hg}$ ) levels in Rapana venosa (Valenciennes, 1846), Eriphia verrucosa (Forskal, 1775), and sediment samples from the Black Sea littoral (Thrace, Turkey). Mar. Pollut. Bull. 95:215-222. https://doi.org/10.1016/j. marpolbul.2015.04.016

Olayinka OO, Adewusi AA, Olujimi OO, Aladesida AA (2019) Polycyclic aromatic hydrocarbons in sediment and health risk of fish, crab and shrimp around Atlas Cove. Nigeria. J. Health Pollut. 9:191204. https://doi.org/10.5696/2156-9614-9.24.191204

OECD/European Observatory on Health Systems and Policies (2017) Italy: Country Health Profile 2017, State of Health in the EU, 
OECD Publishing. Paris/European Observatory on Health Systems and Policies, Brussels https://doi.org/10.1787/9789264283428-en

Perry H, Isphording W, Trigg C, Riedel R (2015) Heavy metals in red crabs, Chaceon quinquedens, from the Gulf of Mexico. Mar. Pollut. Bull. 101:845-851. https://doi.org/10.1016/j.marpolbul.2015.11. 020

Perugini M, Visciano P, Giammarino A, Manera M, Di Nardo W, Amorena M (2007) Polycyclic aromatic hydrocarbons in marine organisms from the Adriatic Sea, Italy. Chemosphere 66:19041910. https://doi.org/10.1016/j.chemosphere.2006.07.079

Petrik A, Thiombane M, Lima A, Albanese S, Buscher JT, De Vivo B (2018) Soil contamination compositional index: a new approach to quantify contamination demonstrated by assessing compositional source patterns of potentially toxic elements in the Campania Region (Italy). App. Geochemistry 96:264-276. https://doi.org/10. 1016/j.apgeochem.2018.07.014

Pinheiro MA, Silva PP, Duarte LF, Almeida AA, Zanotto FP (2012) Accumulation of six metals in the mangrove crab Ucides cordatus (Crustacea: Ucididae) and its food source, the red mangrove Rhizophora mangle (Angiosperma: Rhizophoraceae). Ecotoxicol. Environ. Saf. 81:114-121. https://doi.org/10.1016/j.ecoenv.2012. 05.004

Ramos-Miras, J.J., Sanchez-Muros, M.J., Morote, E., Torrijos, M., Gil, C., Zamani-Ahmadmahmoodi, R., Rodríguez Martin, J.A. , 2019. Potentially toxic elements in commonly consumed fish species from the western Mediterranean Sea (Almería Bay): bioaccumulation in liver and muscle tissues in relation to biometric parameters. Sci. Total Environ. 671, 280-287. https://doi.org/10.1016/j.scitotenv. 2019.03.359.

Serpe FP, Esposito M, Gallo P, Serpe L (2010) Optimisation and validation of an HPLC method for determination of polycyclic aromatic hydrocarbons (PAHs) in mussels. Food chem. 122:920-925. https:// doi.org/10.1016/j.foodchem.2010.03.062

Sofoulaki K, Kalantzi I, Machias A, Mastoraki M, Chatzifotis S, Mylona K, Pergantis SA, Tsapakis M (2018) Metals and elements in sardine and anchovy: species specific differences and correlations with proximate composition and size. Sci. Total Environ. 645:329-338. https://doi.org/10.1016/j.scitotenv.2018.07.133

Spink DC, Wu SJ, Spink BC, Hussain MM, Vakharia DD, Pentecost BT, Kaminsky LS (2008) Induction of CYP1A1 and CYP1B1 by benzo(k)fluoranthene and benzo(a)pyrene in T-47D human breast cancer cells: roles of PAH interactions and PAH metabolites. Toxicol. Appl. Pharmacol. 226:213-224. https://doi.org/10.1016/j. taap.2007.08.024
Suner MA, Devesa V, Munoz O, Lopez F, Montoro R, Arias AM, Blasco $\mathrm{J}$ (1999) Total and inorganic arsenic in the fauna of the Guadalquivir estuary: environmental and human health implications. Sci. Total Environ. 242:261-270. https://doi.org/10.1016/S0048-9697(99) 00399-X

Tiwari M, Sahu SK, Pandit GG (2017) Distribution of PAHs in different compartment of creek ecosystem: ecotoxicological concern and human health risk. Environ Toxicol Pharmacol. 50:58-66. https://doi. org/10.1016/j.etap.2017.01.008

Topcuoğlu S, Kırbașoğlu C, Güngör N (2002) Heavy metals in organisms and sediments from Turkish Coast of the Black Sea, 1997-1998. Environ. Int. 27:521-526. https://doi.org/10.1016/s0160-4120(01) 00099-x

Tornero, V., Hanke, G., 2016. Chemical contaminants entering the marine environment from sea-based sources: a review with a focus on European Seas. Mar. Pollut. Bull. 112, 17-38. 10.1016/ j.marpolbul.2016.06.091. UNI/EN/ISO/IEC 17025, 2005. General Requirements for the Competence of Testing and Calibration Laboratories.

Vinogradov AP (2018) Memoir II: the elementary chemical composition of marine organisms. Yale University, Sears Foundation for Marine Research

Wiech M, Frantzen S, Duinker A, Rasinger JD, Maage A (2020) Cadmium in brown crab Cancer pagurus. Effects of location, season, cooking and multiple physiological factors and consequences for food safety. Sci. Total Environ. 703, 134922. 703:134922. https:// doi.org/10.1016/j.scitotenv.2019.134922

Zaccaroni A, Andreini R, Franzellitti S, Barceló D, Eljarrat E (2018) Halogenated flame retardants in stranded sperm whales (Physeter macrocephalus) from the Mediterranean Sea. Sci. Total Environ. 635:892-900. https://doi.org/10.1016/j.scitotenv.2018.04.147

Zhang C, Li Y, Wang C, Feng Z, Hao Z, Yu W, Wang T, Zou X (2020) Polycyclic aromatic hydrocarbons (PAHs) in marine organisms from two fishing grounds, South Yellow Sea, China: bioaccumulation and human health risk assessment. Mar. Pollut. Bull. 153: 110995. https://doi.org/10.1016/j.marpolbul.2020.110995

Zotti M, Del Coco L, De Pascali SA, Migoni D, Vizzini S, Mancinelli G, Fanizzi FP (2016) Comparative analysis of the proximate and elemental composition of the blue crab Callinectes sapidus, the warty crab Eriphia verrucosa, and the edible crab Cancer pagurus. Heliyon 2:e00075. https://doi.org/10.1016/j.heliyon.2016.e00075

Publisher's note Springer Nature remains neutral with regard to jurisdictional claims in published maps and institutional affiliations. 